\title{
GLOMERULONEPHRITIS. A SURVEY OF THE FUNCTIONAL ORGANIZATION OF THE KIDNEY IN VARIOUS STAGES OF DIFFUSE GLOMERULONEPHRITIS ${ }^{1}$
}

\author{
By DAVID P. EARLE, JR., JOHN V. TAGGART, AND JAMES A. SHANNON \\ (From the Research Service, Third New York University Medical Division, The Goldwater \\ Memorial Hospital, Welfare Island, New York, and the Department of Medicine, \\ New York University College of Medicine, New York City)
}

(Received for publication August 9, 1943)

Several studies of the functional changes which are encountered in chronic renal disease include observations on individuals with diffuse glomerulonephritis ( 1 to 3 ). However, the information on glomerulonephritis contained in such studies is meager. This fact, together with the diversity in the manifestations of the disease, precludes a description of its characteristics of renal function from the data available. The present study was designed to satisfy this deficiency in our information and has two specific ends in view. The first is to test the applicability of some of the more modern techniques of evaluating renal function to the situation obtaining in this condition. The second is to obtain a description of the characteristic pattern of functional activity of the kidney in glomerulonephritis. These ends have been achieved and it is now possible to formulate investigations of some of the more specific functional aspects of the disease by subsequent studies of a more limited scope.

Observations have been made on 22 patients with well-documented diffuse glomerulonephritis. The patients studied were selected so that the group contains a fair representation of the different stages of the disease, from a few weeks after its acute inception to shortly before its termination. The general and renal status of each patient were assayed by the usual clinical techniques, as well as by those which yield information on some of the discrete functions of the kidney. Among the latter functions are included the minimal renal plasma flow and blood flow, the glomerular filtration rate, and the maximal rate of tubular excre-

1 This investigation has been aided in part by a grant from the Carnegie Corporation of New York.

The authors are indebted to Sharp and Dohme for generously supplying the sterile ampules of mannitol used in these studies and to the Warner Institute for Therapeutic Research for a supply of inulin in sterile ampules. tion of diodrast. These functions were studied in such a way that some of the important relationships between the discrete renal functions can be examined.

\section{CASE MATERIAL}

Patients were derived from several sources. 2 Each was observed for a sufficient period of time to insure a fairly secure diagnosis of diffuse glomerulonephritis before inclusion in the group. Some of the pertinent facts relative to the diagnosis, onset, and course of the disease in each patient are summarized in Table I. Information on the status of the patient just prior to the first experimental observation and the duration of the disease at this time is included (Columns 4 and 5). The type of the onset and the presenting symptoms and signs, as far as these could be determined, are noted, as well as the presence or absence of exacerbations (Column 6). The criterion for the latter diagnosis has been accepted as "an abrupt and marked increase in the degree of hematuria" (4).

Specific note is taken of infections in relation to the onset of the disease (Columns 7 and 8) and of the presence or absence of a nephrotic phase (Column 9) because of the bearing of these factors on the diagnosis. There is common agreement that the acute inception of diffuse glomerulonephritis and the exacerbation are typically preceded by an upper respiratory infection, generally associated with the presence of group $A$ hemolytic streptococci. The latent period between the onset of the infection and that of the nephritis is usually 10 days to 3 weeks, while the latent period between the infection and the ex-

2 The authors are indebted to Dr. David Seegal of the 1st (Columbia) Research Service, Goldwater Memorial Hospital, New York City, for referring patients 4, 8, 11, $13,15,16,17,18$, and 20 and permitting the use of the clinical records of these patients; to Dr. Duncan Clark and Dr. B. T. Tiernan of the Long Island College of Medicine for referring patients $1,2,12$, and 22; to $\mathrm{Dr}$. Abraham W. Victor of the Queens General Hospital, New York City, for referring patients 3,6, 9, and 14; and to Dr. Shepard Shapiro of New York City for referring patients 10 and 19. Patients 5, 7, and 21 were drawn from the 3rd (NYU) Medical Service, Goldwater Memorial Hospital, New York City. 
acerbation is 1 to 4 days $(4,5)$. Furthermore, a definite nephrotic syndrome is a common intercurrent manifestation of chronic diffuse glomerulonephritis, but except for true lipoid nephrosis is rarely found in other renal diseases (6). Generalized edema, serum albumin below 2.5 grams per $100 \mathrm{ml}$., and serum cholesterol above $400 \mathrm{mgm}$. per cent have been accepted in the present study as evidence of the presence of the nephrotic syndrome.

Information is also contained on the course of the disease (Column 10). The occurrence of infections during the period of observation (Column 11) is noted because of a possible influence on the progression of the disease $(4,5,7)$.

The information available on each case (Table I) leaves little doubt of the validity of the primary diagnosis although the duration of the disease in each case is less certain.

\section{EXPERIMENTAL PROCEDURE}

The several renal functions measured were evaluated under standard conditions. The patients were maintained at bed rest and allowed no food or water from the time of the preceding evening meal until the completion of the experimental run. Experiments were begun between 8:00 and 9:00 A.M. and were from 2 to $21 / 2$ hours' duration. Studies were not performed if the patient's temperature was above $100^{\circ} \mathrm{F}$. (rectal).

The routine procedure was as follows: Simultaneous mannitol and diodrast clearances were determined at constant plasma concentrations of each, during 3 consecutive periods of approximately 15 minutes' duration. The plasma diodrast level was then raised and after allowing 20 to 30 minutes for stabilization of the plasma diodrast concentration, diodrast $\mathrm{Tm}$ was determined in 3 additional 15-minute periods. Appropriate amounts of mannitol and diodrast to sustain the desired plasma concentration were administered throughout each experimental run by an infusion given at a rate of $2 \mathrm{ml}$. per minute. Mid-period bloods were obtained by venipuncture from the antecubital vein. Urine samples were obtained by catheter and followed, in all cases, by a bladder wash with sterile water.

The minimal renal plasma flow has been taken as equal to the diodrast clearance at low plasma levels (see below). Minimal renal blood flow has been calculated from this value and a hematocrit determination obtained at the beginning of the experiment $(8,9)$. Glomerular filtration rate has been taken as being equal to the mannitol clearance ( 8 to 11$)$. The calculations involved in each of these measurements, together with that of diodrast $\mathrm{Tm}$, followed the usual methods.

Tubular excretion of diodrast was examined in a limited number of experiments during a progressive increase of the plasma concentration of diodrast. A gradually rising plasma level was obtained as follows: An infusion containing a sufficient concentration of diodrast to sustain the plasma diodrast iodine at approximately $1 \mathrm{mgm}$. per cent was started at a rate of $2 \mathrm{ml}$. per minute. A more concentrated solution of diodrast was then added slowly by gravity to the initial infusion so that there was a progressive increase in the concentration of diodrast in the infusion fluid throughout the experimental observation. Thorough mixing of the infusion fluid was assured by the use of a stirring rod driven by a small electric motor. These arrangements may be adjusted to produce a steady increase in plasma diodrast of whatever rate is desired.

\section{METHODS}

1. Diodrast. Diodrast iodine in the plasma and urine was determined by a modification (12) of the Alpert method (13). Protein-free filtrates of plasma and urine were prepared using cadmium (14) and the filtrates treated with bromine in the usual fashion. The flasks containing the bromine-treated filtrates were chilled in an ice bath prior to the addition of $\mathrm{Kl}$ and titration with thiosulfate. Chilling the solution just prior to the titration produces a sharp and relatively stable end-point for the titration.

Plasma contains a definite and measurable blank with this procedure. The blank is in the order of magnitude of 0.1 to $0.2 \mathrm{mgm}$. per cent diodrast iodine in the plasma of normal individuals but has been observed as high as $0.5 \mathrm{mgm}$. per cent in plasma from some individuals with excessive nitrogen retention. Because of the variability of the blank, it was determined routinely by an analysis of plasma, obtained prior to the administration of diodrast. A plasma filtrate was prepared in the usual manner and titrated subsequent to the addition of $\mathrm{KlO}_{3}$. The urines of individuals with nitrogen retention may also contain a blank of considerable magnitude. This was estimated in a similar manner and expressed in mgms. of diodrast iodine excreted per unit time.

Recoveries of diodrast added to the plasma, when corrected for such a blank, were found to be quite constant but were only 94 per cent of the theoretical. These findings account for the fact that previous experience with the method (13) showed it to yield 100 per cent recovery at diodrast iodine values below $4 \mathrm{mgm}$. per cent, with progressively less at higher concentrations. The magnitude of the plasma blank is usually sufficient to balance the small loss of diodrast at the low plasma concentrations.

2. Mannitol and inulin. The method described by Smith, Finkelstein, and Smith (11) was used for the determination of mannitol except that the plasma and urine filtrates were oxidized at room temperature for 90 minutes (12) instead of for a shorter time in a boiling water bath. Protein-free filtrates of plasma were obtained using cadmium (14) except in the experiments where mannitol and inulin clearances were determined simultaneously. In these instances, both analyses were on a filtrate prepared with zinc (15). Inulin was determined by Harrison's (16) modification of the colorimetric method of Alving, Rubin, and Miller (17). Recoveries of known amounts of mannitol and inulin added to plasma and urine were excellent.

3. Plasma proteins. Total plasma protein and albumin 
TABLE I

Clinical data concerning onset and course of diffuse glomerulonephritis

\begin{tabular}{|c|c|c|c|c|c|c|c|c|c|c|}
\hline 1 & 2 & 3 & 4 & 5 & 6 & 7 & 8 & 9 & 10 & 11 \\
\hline $\begin{array}{c}\text { Case } \\
\text { num- } \\
\text { ber }\end{array}$ & Sex & $\underset{\text { in }}{\text { Age }}$ & $\begin{array}{l}\text { Status of } \\
\text { nephritis } \\
\text { at first } \\
\text { test }\end{array}$ & $\begin{array}{l}\text { Duration of } \\
\text { nephritis } \\
\text { before } \\
\text { first test }\end{array}$ & Onset of nephritis & $\begin{array}{l}\text { Infection } \\
\text { preceding } \\
\text { onset of } \\
\text { nephritis }\end{array}$ & $\begin{array}{l}\text { Latent } \\
\text { period }\end{array}$ & $\begin{array}{l}\text { Neph- } \\
\text { rotic } \\
\text { phase }\end{array}$ & Course of nephritis & $\begin{array}{c}\text { Infections during } \\
\text { observation }\end{array}$ \\
\hline 1 & $\mathbf{M}$ & 13 & Healed & 18 months & $\begin{array}{l}\text { Acute: Smoky } \\
\text { urine. Facial } \\
\text { edema. Convul- } \\
\text { sion. BP: } \\
170 / 125 \text {, fell to } \\
110 / 60\end{array}$ & Pharyngitis & 3 weeks & No & $\begin{array}{l}\text { Apparently } \\
\text { healed } 14 \text { weeks } \\
\text { after onset }\end{array}$ & None \\
\hline 2 & $\mathbf{M}$ & 25 & Healed & $4 \frac{1}{2}$ months & $\begin{array}{l}\text { Acute: Smoky } \\
\text { urine. Facial } \\
\text { edema. Pain in } \\
\text { back. BP: } \\
160 / 100 \text {, fell to } \\
115 / 70\end{array}$ & Pharyngitis & 3 weeks & No & $\begin{array}{l}\text { Apparently } \\
\text { healed some } \\
\text { time after } 2 \\
\text { months }\end{array}$ & None \\
\hline 3 & $\mathbf{M}$ & 14 & Healing & 5 weeks & $\begin{array}{l}\text { Acute: Micro- } \\
\text { scopic hema- } \\
\text { turia. Nocturia. } \\
\text { Ankle edema. } \\
\text { BP: } 180 / 130 \text {, } \\
\text { fell to } 100 / 60\end{array}$ & Pharyngitis & 2 weeks & No & $\begin{array}{l}\text { Apparently } \\
\text { healed at or } \\
\text { shortly after } \\
\text { time of first } \\
\text { test }\end{array}$ & None \\
\hline 4 & $\mathbf{F}$ & 13 & Acute & 3 months & $\begin{array}{l}\text { Acute: Micro- } \\
\text { scopic hema- } \\
\text { turia. Puffy } \\
\text { eyes. Ankle } \\
\text { edema. BP: } \\
170 / 95 \text {, fell to } \\
125 / 70\end{array}$ & $\begin{array}{l}\text { Pharyngitis } \\
\text { (Group A } \\
\text { hemolytic } \\
\text { streptococ- } \\
\text { cus proven) }\end{array}$ & 2 weeks & No & $\begin{array}{l}\text { Edema and hy- } \\
\text { pertension dis- } \\
\text { appeared but } \\
\text { urine abnormali- } \\
\text { ties persisted }\end{array}$ & $\begin{array}{l}\text { Fever } 99 \text { to } \\
100.6^{\circ} \text { until } \\
\text { after } 2 \text { nd test }\end{array}$ \\
\hline 5 & $\mathbf{M}$ & 22 & Acute & 3 weeks & $\begin{array}{l}\text { Acute: Micro- } \\
\text { scopic hema- } \\
\text { turia. Edema } \\
\text { Dyspnea. BP: } \\
160 / 106 \text {, fell to } \\
115 / 80\end{array}$ & $\begin{array}{l}\text { Head cold } \\
\text { Pharyngitis } \\
\text { Otitis media }\end{array}$ & $\begin{array}{l}3 \text { weeks } \\
2 \text { weeks } \\
\text { ? days }\end{array}$ & No & $\begin{array}{l}\text { Symptoms dis- } \\
\text { appeared. Urine } \\
\text { improving rap- } \\
\text { idly when last } \\
\text { seen }\end{array}$ & None \\
\hline 6 & $\mathbf{M}$ & 12 & Acute & 6 weeks & $\begin{array}{l}\text { Acute: Micro- } \\
\text { scropic hema- } \\
\text { turia. Puffy } \\
\text { eyes. BP: } \\
170 / 120 \text {, fell to } \\
140 / 70\end{array}$ & Head cold & $\begin{array}{c}4 \text { to } 6 \\
\text { weeks }\end{array}$ & No & $\begin{array}{l}\text { Apparently } \\
\text { healed between } \\
\text { second and } \\
\text { third tests }\end{array}$ & None \\
\hline 7 & $\mathbf{M}$ & 44 & Chronic & $\begin{array}{l}7 \text { months } \\
\text { or more }\end{array}$ & $\begin{array}{l}\text { Acute (?Exacer- } \\
\text { bation): Micro- } \\
\text { scopic hema- } \\
\text { turia. Facial } \\
\text { edema. Ankle } \\
\text { edema. BP: } \\
170 / 100 \text {, fell to } \\
140 / 85\end{array}$ & Head cold & 1 day & No & $\begin{array}{l}\text { No change during } \\
\text { observation. } \\
\text { Retrograde py- } \\
\text { elograms nega- } \\
\text { tive }\end{array}$ & None \\
\hline 8 & $\mathbf{M}$ & 14 & Chronic & $\begin{array}{l}17 \text { months } \\
\text { or more } \\
9 \text { months }\end{array}$ & \begin{tabular}{|} 
Insidious: Rou- \\
tine urine \\
showed albumin. \\
Facial edema. \\
Ankle edema
\end{tabular} & $?$ & & Yes & $\begin{array}{l}\text { Mild nephrotic } \\
\text { syndrome } \\
\text { throughout ob- } \\
\text { servation }\end{array}$ & $\begin{array}{l}\text { Upper respira- } \\
\text { tory infection } \\
\text { and catarrhal } \\
\text { otitis media, } 4 \\
\text { days after 1st } \\
\text { test. } \\
\text { Head colds at } \\
\text { time of last } \\
\text { two tests }\end{array}$ \\
\hline
\end{tabular}


TABLE I-Continued

\begin{tabular}{|c|c|c|c|c|c|c|c|c|c|c|}
\hline 1 & 2 & 3 & 4 & 5 & 6 & 7 & 8 & 9 & 10 & 11 \\
\hline $\begin{array}{c}\text { Case } \\
\text { numb- } \\
\text { ber }\end{array}$ & Sex & $\begin{array}{c}\text { Age } \\
\text { in } \\
\text { years }\end{array}$ & $\left|\begin{array}{c}\text { Status of } \\
\text { nephritis } \\
\text { at first } \\
\text { test }\end{array}\right|$ & $\begin{array}{l}\text { Duration of } \\
\text { nephritis } \\
\text { before } \\
\text { first test }\end{array}$ & Onset of nephritis & $\begin{array}{l}\text { Infection } \\
\text { preceding } \\
\text { onset of } \\
\text { nephritis }\end{array}$ & $\begin{array}{l}\text { Latent } \\
\text { perlod }\end{array}$ & $\begin{array}{l}\text { Neph- } \\
\text { rotic } \\
\text { phase }\end{array}$ & Course of nephritis & $\begin{array}{l}\text { Infections during } \\
\text { observation }\end{array}$ \\
\hline 9 & $\mathbf{F}$ & 41 & Acute & $2 \frac{1}{2}$ months & \begin{tabular}{|l|} 
Acute: Gross \\
hematuria. Gen- \\
eralized edema. \\
BP: 170/90, feil \\
to $120 / 80$. (Pre- \\
vious urines and \\
BP normal)
\end{tabular} & Pharyngitis & 2 weeks & No & \begin{tabular}{|} 
Steady clinical \\
improvement \\
throughout ob- \\
servation but \\
urine did not \\
clear entirely
\end{tabular} & $\begin{array}{l}\text { Draining ab- } \\
\text { dominal sinus } \\
\text { one year, com. } \\
\text { pletely healed } \\
\text { by third test }\end{array}$ \\
\hline 10 & $\mathbf{M}$ & 31 & Chronic & 8 years & $\begin{array}{l}\text { Acute: Gross } \\
\text { hematuria. Oli- } \\
\text { guria. Burning } \\
\text { on urination }\end{array}$ & Pharyngitis & $?$ & No & $\begin{array}{l}\text { Recurrence of } \\
\text { gross hematuria } \\
4 \text { years ago, mi- } \\
\text { croscopic hema- } \\
\text { turia ever since. } \\
\text { I. V. and retro- } \\
\text { grade pyelo- } \\
\text { grams negative }\end{array}$ & None \\
\hline 11 & $\mathbf{M}$ & 18 & Chronic & 6 to 7 years & $\begin{array}{l}\text { Insidious: Ankle } \\
\text { edema }\end{array}$ & $?$ & & & & \\
\hline & & & & 13 months & \begin{tabular}{|l|} 
Exacerbation: \\
Microscopic \\
hematuria. Fa- \\
cial edema. Leg \\
edema. BP: \\
$160 / 115$, fell to \\
$135 / 100$
\end{tabular} & Pharyngitis & 1 day & Yes & $\begin{array}{l}\text { Nephrotic syn- } \\
\text { drome cleared } \\
\text { up approxi- } \\
\text { mately } 2 \text { months } \\
\text { before first test }\end{array}$ & $\begin{array}{l}\text { Pharyngitis } \\
\text { (No strepto- } \\
\text { coccus demon- } \\
\text { strated), } 2 \\
\text { weeks before } \\
\text { 1st test. }\end{array}$ \\
\hline 12 & F & 15 & Chronic & 10 months & $\begin{array}{l}\text { Acute: Gross } \\
\text { hematuria. Fa- } \\
\text { cial edema. } \\
\text { BP: } 140 / 104, \\
\text { fell to } 115 / 80\end{array}$ & Head cold & $\begin{array}{l}4 \text { to } 5 \\
\text { days }\end{array}$ & Yes & & \\
\hline & & & & & \begin{tabular}{|l} 
Exacerbation: \\
Gross hematuria
\end{tabular} & Pharyngitis & 1 day & & $\begin{array}{l}\text { Unobserved epi- } \\
\text { sode } 7 \text { months } \\
\text { before last test } \\
\text { suggestive of ex- } \\
\text { acerbation. } \\
\text { Asymptomatic } \\
\text { at time of last } \\
\text { test }\end{array}$ & $\begin{array}{l}\text { Pharyngitis } \\
\text { (not observed) }\end{array}$ \\
\hline 13 & $\mathbf{M}$ & 21 & Chronic & $1 \frac{1}{2}$ years & $\begin{array}{l}\text { Insidious: Rou- } \\
\text { tine urine } \\
\text { showed albumin } \\
\text { (urine negative } \\
\text { one year before) }\end{array}$ & ? & & Yes & $\begin{array}{l}\text { Losing edema } \\
\text { during obser- } \\
\text { vation }\end{array}$ & $\begin{array}{l}\text { Chronic sinusi- } \\
\text { tis and bron- } \\
\text { chitis through- } \\
\text { out observa- } \\
\text { tion period }\end{array}$ \\
\hline 14 & $\mathbf{F}$ & 54 & Chronic & $\begin{array}{l}6 \text { months } \\
\text { or more }\end{array}$ & $\begin{array}{l}\text { Insidious: Ana- } \\
\text { sarca }\end{array}$ & None noted & & Yes & $\begin{array}{l}\text { Nephrotic during } \\
\text { observation, but } \\
\text { edema re-- } \\
\text { sponded in part } \\
\text { to mercupurin }\end{array}$ & $\begin{array}{l}\text { Cellulitis of leg, } \\
\text { responded to } \\
\text { sulfadiazine, } 1 \\
\text { week before } \\
\text { 1st test. }\end{array}$ \\
\hline 15 & $\mathbf{F}$ & 19 & Chronic & 2 months & $\begin{array}{l}\text { Acute: Gross } \\
\text { hematuria. } \\
\text { Back pain. } \\
\text { BP: ? } \\
\text { Exacerbation: } \\
\text { Gross hema- } \\
\text { turia. Back } \\
\text { pain. Facial } \\
\text { edema. Ankle } \\
\text { edema. BP: } \\
170 / 100 \text {, fell to } \\
120 / 60\end{array}$ & $?$ & & No & \begin{tabular}{|l|} 
Four exacerba- \\
tions in chronic \\
glomerulo- \\
nephritis
\end{tabular} & $\begin{array}{l}\text { Chronic puru- } \\
\text { lent sinusitis. } \\
\text { 1 month before } \\
\text { 5th test. } \\
\text { Phlebitis leg, } \\
\text { 1 month before } \\
\text { 6th test. } \\
\text { Pharyngitis } \\
\text { twice (not ob- } \\
\text { served) }\end{array}$ \\
\hline
\end{tabular}


TABLE I-Continued

\begin{tabular}{|c|c|c|c|c|c|c|c|c|c|c|}
\hline 1 & 2 & 3 & 4 & 5 & 6 & 7 & 8 & 9 & 10 & 11 \\
\hline $\begin{array}{c}\text { Case } \\
\text { num- } \\
\text { ber }\end{array}$ & Sex & $\begin{array}{c}\text { Age } \\
\text { in } \\
\text { years }\end{array}$ & $\begin{array}{c}\text { Status of } \\
\text { nephritis } \\
\text { at first } \\
\text { test }\end{array}$ & $\begin{array}{c}\text { Duration of } \\
\text { nephritis } \\
\text { before } \\
\text { first test }\end{array}$ & Onset of nephritis & $\begin{array}{l}\text { Infection } \\
\text { preceding } \\
\text { onset of } \\
\text { nephritis }\end{array}$ & $\begin{array}{l}\text { Latent } \\
\text { period }\end{array}$ & $\begin{array}{l}\text { Neph- } \\
\text { rotic } \\
\text { phase }\end{array}$ & Course of nephritis & $\begin{array}{l}\text { Infections during } \\
\text { obeervation }\end{array}$ \\
\hline 16 & $\mathbf{F}$ & 21 & Chronic & 10 months & $\begin{array}{l}\text { Acute: Gross } \\
\text { hematuria. } \\
\text { Purpura. BP: } \\
140 / 90\end{array}$ & Pharyngitis & 2 weeks & No & $\begin{array}{l}\text { Marked progres- } \\
\text { sion of disease } \\
\text { in } 8 \text { months } \\
\text { between second } \\
\text { and third test, } \\
\text { no history of in- } \\
\text { fection } \\
\text { Died } 7 \text { weeks } \\
\text { after last test. } \\
\text { No autopsy }\end{array}$ & $\begin{array}{l}\text { Grippe, temp.: } \\
102^{\circ} \text {. day be- } \\
\text { fore first test }\end{array}$ \\
\hline 17 & $\mathbf{M}$ & 35 & Chronic & $\begin{array}{l}9 \text { years } \\
\text { or more }\end{array}$ & $\begin{array}{l}\text { Insidious: Rou- } \\
\text { tine urine } \\
\text { showed albumin }\end{array}$ & ? "Grippe" & 1 week & No & $\begin{array}{l}\text { Hypertension } \\
\text { first noted } 4 \\
\text { years ago. } \\
\text { Gradual progres- } \\
\text { sion of disease } \\
\text { during observa- } \\
\text { tion. Died } 7 \\
\text { months after } \\
\text { last test } \\
\text { Autopsy: Chronic } \\
\text { glomerulo } \\
\text { nephritis }\end{array}$ & None \\
\hline 18 & $\mathbf{M}$ & 58 & Chronic & $\begin{array}{l}2 \text { months, } \\
\text { probably } \\
\text { much } \\
\text { longer }\end{array}$ & $\begin{array}{l}\text { Insidious: Ana- } \\
\text { sarca }\end{array}$ & None noted & & Yes & $\begin{array}{l}\text { Died in uremia } \\
3 \frac{1}{2} \text { months after } \\
\text { first test. Au- } \\
\text { topsy: Chronic } \\
\text { glomerulo- } \\
\text { nephritis }\end{array}$ & None \\
\hline 19 & $\mathbf{F}$ & 23 & Chronic & 6 years & $\begin{array}{l}\text { Acute: Puffy face. } \\
\text { Ankle edema. } \\
\text { ? hematuria. } \\
\text { BP: ? }\end{array}$ & Pharyngitis & $?$ & Yes & $\begin{array}{l}\text { Nephrotic phase } \\
\text { cleared up ap- } \\
\text { proximately } 6 \\
\text { months before } \\
\text { first test }\end{array}$ & None \\
\hline 20 & $\mathbf{M}$ & 53 & Chronic & $\begin{array}{l}6 \text { years } \\
\text { or more }\end{array}$ & $\begin{array}{l}\text { Insidious: Inter- } \\
\text { mittent ankle } \\
\text { edema }\end{array}$ & None noted & & No & $\begin{array}{l}\text { Died in uremia } 1 \\
\text { week after last } \\
\text { test. No au- } \\
\text { topsy }\end{array}$ & None \\
\hline 21 & $\mathbf{M}$ & 47 & Chronic & $\begin{array}{l}4 \frac{1}{2} \text { years } \\
\text { or more }\end{array}$ & $\begin{array}{l}\text { Insidious: Ankle } \\
\text { edema. Facial } \\
\text { edema }\end{array}$ & None noted & & Yes & $\begin{array}{l}\text { Nephrotic phase } \\
\text { cleared up } 10 \\
\text { months before } \\
\text { first test. Died } \\
\text { in uremia } \\
4 \text { months after } \\
\text { last test. Au- } \\
\text { topsy: Chronic } \\
\text { glomerulo- } \\
\text { nephritis and } \\
\text { renal amy- } \\
\text { loidosis }\end{array}$ & None \\
\hline 22 & $\mathbf{M}$ & 24 & Chronic & $\begin{array}{l}2 \text { years } \\
\text { or more }\end{array}$ & $\begin{array}{l}\text { Insidious: Noc- } \\
\text { turia. Polyuria. } \\
\text { Frequency. }\end{array}$ & None noted & & No & $\begin{array}{l}\text { Coma and nitro- } \\
\text { gen retention } 6 \\
\text { months before } \\
\text { first test. Ret- } \\
\text { trograde pyelo- } \\
\text { grams negative }\end{array}$ & None \\
\hline
\end{tabular}


were determined by the micro-Kjeldahl method (18) after precipitation by the Howe technique (19).

4. Quantitative estimations of the 12-hour urinary excretion of albumin and formed elements were performed by the method of Addis (20).

\section{VALIDITY OF FUNCTIONAL MEASUREMENTS}

The measurement of glomerular filtration rate. The plasma clearance of mannitol has been accepted, in these studies as a precise expression of the rate of glomerular filtration. This judgment was tentatively based upon those facts which lead one to suppose that the plasma clearance of inulin is such a measure in the normal (10) and diseased kidney (21) and the demonstration that inulin and mannitol clearances are identical in normal man and in women with preeclampsia and eclampsia (11). A similar situation appears to obtain in glomerulonephritis (Table II).

The comparison of the inulin and mannitol clearances was limited to 7 patients (mannitol clearances ranging from 8.0 to $104.0 \mathrm{ml}$. per minute) and were incidental to the routine observations. The two clearances were not completely identical in several of the patients. However, the differences are small and the filtrate fractions by the mannitol or inulin clearances are much the same. For the present purposes, then, the mannitol clearance may be considered to be an adequate measure of glomerular filtration in glomerulonephritis. It is accepted that for other purposes a more extensive comparison of the two clearances may be desirable.

These observations may be taken to indicate that the changes in the glomerular membrane in glomerulonephritis are not such as to preferen- tially interfere with the filtration of such a large molecule as inulin $(10,21)$ as compared to the filtration of a small molecule, such as mannitol. Similarly, the reabsorption of such a small molecule as mannitol is not facilitated by the changes in the tubular barrier.

The measurement of minimal renal plasma flow. The concepts underlying the use of the diodrast clearance for this measurement are well accepted. It may be stated arbitrarily that the diodrast clearance at low plasma concentrations, except in so far as the diodrast in erythrocytes contributes to that currently secreted, is a measure of the minimal renal plasma flow in any situation. However, its general usefulness in functional studies is largely derived from the fact that, in the normal kidney and under certain circumstances in the abnormal kidney, it also constitutes a close approximation of the actual renal plasma flow to the functional elements of the kidney (21). The measurement is still of some value in the absence of such a correlation, but the information in this circumstance is less generally useful.

The advanced stages of glomerulonephritis constitute a condition wherein the mechanism for the tubular transfer of diodrast is severely damaged, or the loss of renal tubular elements is so great, that the diodrast clearance at low plasma concentrations departs widely from the actual renal plasma flow. Calculations of the filtrate fraction in such a situation yield values which are higher than those which actually obtain at the glomeruli and which have little physiological significance. Such data are of little use in the examination of the hemodynamics of glomerular action.

TABLE II

Comparison of mannitol and inulin clearances in patients with diffuse glomerulonephritis

\begin{tabular}{|c|c|c|c|c|c|}
\hline \multirow{2}{*}{$\begin{array}{l}\text { Patient } \\
\text { number }\end{array}$} & \multirow{2}{*}{ Date } & \multirow{2}{*}{$\begin{array}{l}\text { Mannitol } \\
\text { clearance }\end{array}$} & \multirow{2}{*}{$\frac{\text { Inulin clearance }}{\text { Mannitol clearance }}$} & \multicolumn{2}{|c|}{ Filtrate fraction } \\
\hline & & & & $\frac{\text { Mannitol clearance }}{\text { Diodrast clearance }}$ & $\frac{\text { Inulin clearance }}{\text { Diodrast clearance }}$ \\
\hline $\begin{array}{r}9 \\
9 \\
11 \\
8 \\
13 \\
15 \\
19 \\
18\end{array}$ & $\begin{array}{lr}\text { October } & 28,1942 \\
\text { September } 21,1942 \\
\text { November } & 1,1942 \\
\text { August } & 21,1942 \\
\text { September } & 2,1942 \\
\text { August } & 31,1942 \\
\text { October } & 23,1932 \\
\text { August } & 24,1942\end{array}$ & $\begin{array}{c}\text { ml. per minute } \\
104.0 \\
94.0 \\
88.0 \\
57.4 \\
53.0 \\
38.9 \\
17.8 \\
8.0\end{array}$ & $\begin{array}{l}1.07 \\
1.08 \\
1.04 \\
1.00 \\
0.99 \\
0.97 \\
1.06 \\
1.06\end{array}$ & $\begin{array}{c}\text { per cent } \\
17.2 \\
17.1 \\
20.0 \\
12.0 \\
11.9 \\
8.5 \\
17.6 \\
11.5\end{array}$ & $\begin{array}{c}\text { per cent } \\
18.5 \\
18.5 \\
21.2 \\
12.0 \\
11.9 \\
8.3 \\
18.6 \\
11.9\end{array}$ \\
\hline
\end{tabular}




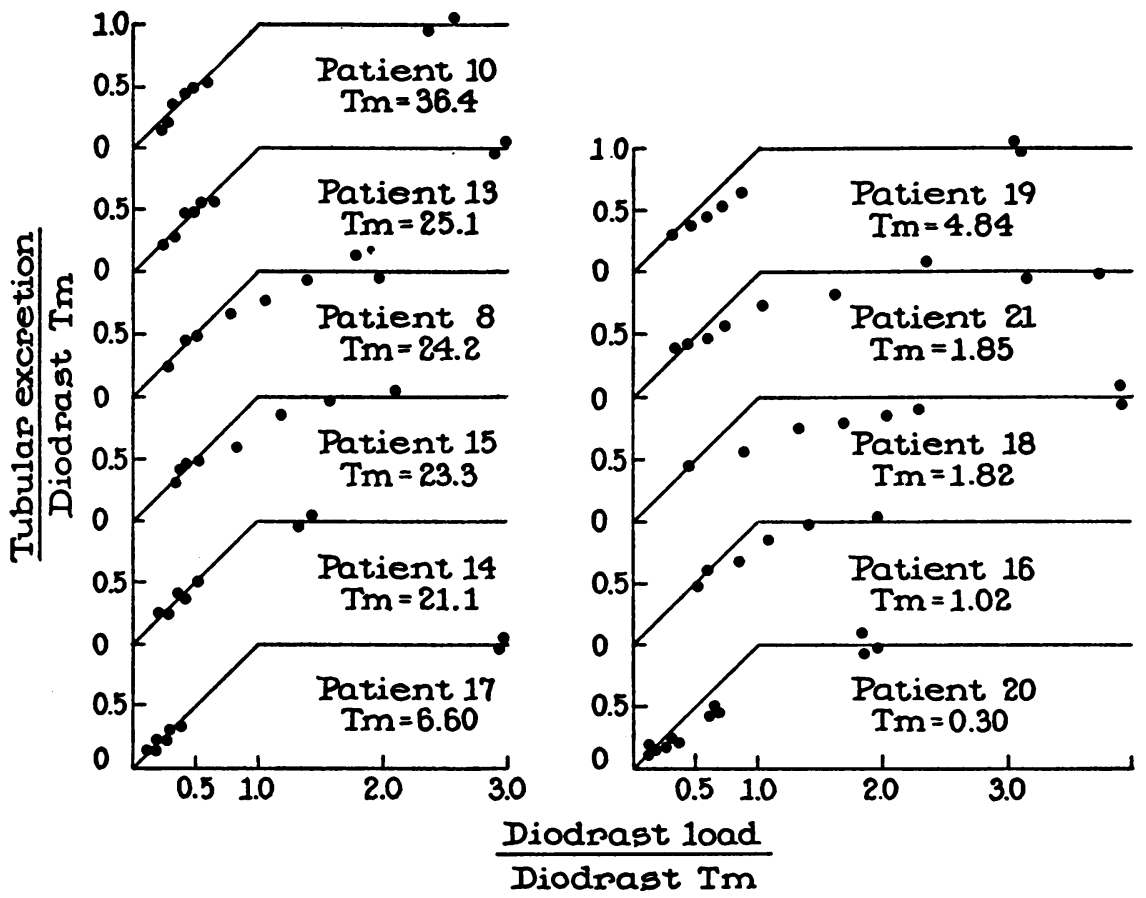

Fig. 1. The Tubular Excretion of Diodrast in Relation to the Load of Diodrast Delivered to the Tubules in a Series of Patients with Diffuse GlomeruloNEPHRITIS

The normal relationship is shown by the solid lines. Tm values are uncorrected for surface area. The 6 experiments at the left of the figure indicate a straight line relationship between the load and tubular excretion of diodrast at diodrast load to diodrast $\mathrm{Tm}$ ratios below 0.5 . The lack of this straight line relationship in the 5 experiments at the right of the figure indicates that true measurements of renal plasma flow could not be obtained in these 5 patients.

It was necessary, for these reasons, to establish the order of magnitude of the tubular impairment which is still compatible with an approximation of the renal plasma flow through a measurement of the diodrast clearance. This was accomplished by studying the tubular excretion of diodrast at different plasma loads in patients with varying amounts of residual renal tissue. The tubular excretion of diodrast in normal subjects is directly proportional to the load of diodrast presented to the tubules until the transport system for diodrast is completely saturated and no further increase in the rate of tubular excretion can occur, i.e., diodrast $\mathrm{Tm}$ has been reached. This circumstance results from a situation which is such that, at the lower diodrast levels, the renal tubular excretion of diodrast is limited by the amount delivered to the renal tubules, while at the higher plasma levels the limitation is within the transfer mechanism itself (22). This relationship is indicated by the solid lines in the graphs of Figure 1 for the normal situation, wherein the transition between the two limitations is quite abrupt (22). The abrupt transition from one limitation to the other does not obtain in certain patients with diffuse glomerulonephritis, as evidenced by a falling off of the observed values from the normal curve as the diodrast load approaches diodrast $\mathrm{Tm}$. This relationship was observed in all patients studied whose Tm values were below $5 \mathrm{mgm}$. per minute and in Patients 8 and 15 (Figure 1) where properly spaced data were obtained. Such a result may be partly a function of the mechanical distribution of blood to tubule tissue and partly the result of a limitation within the tubule cells whereby higher concentrations of diodrast in the extracellular fluid 


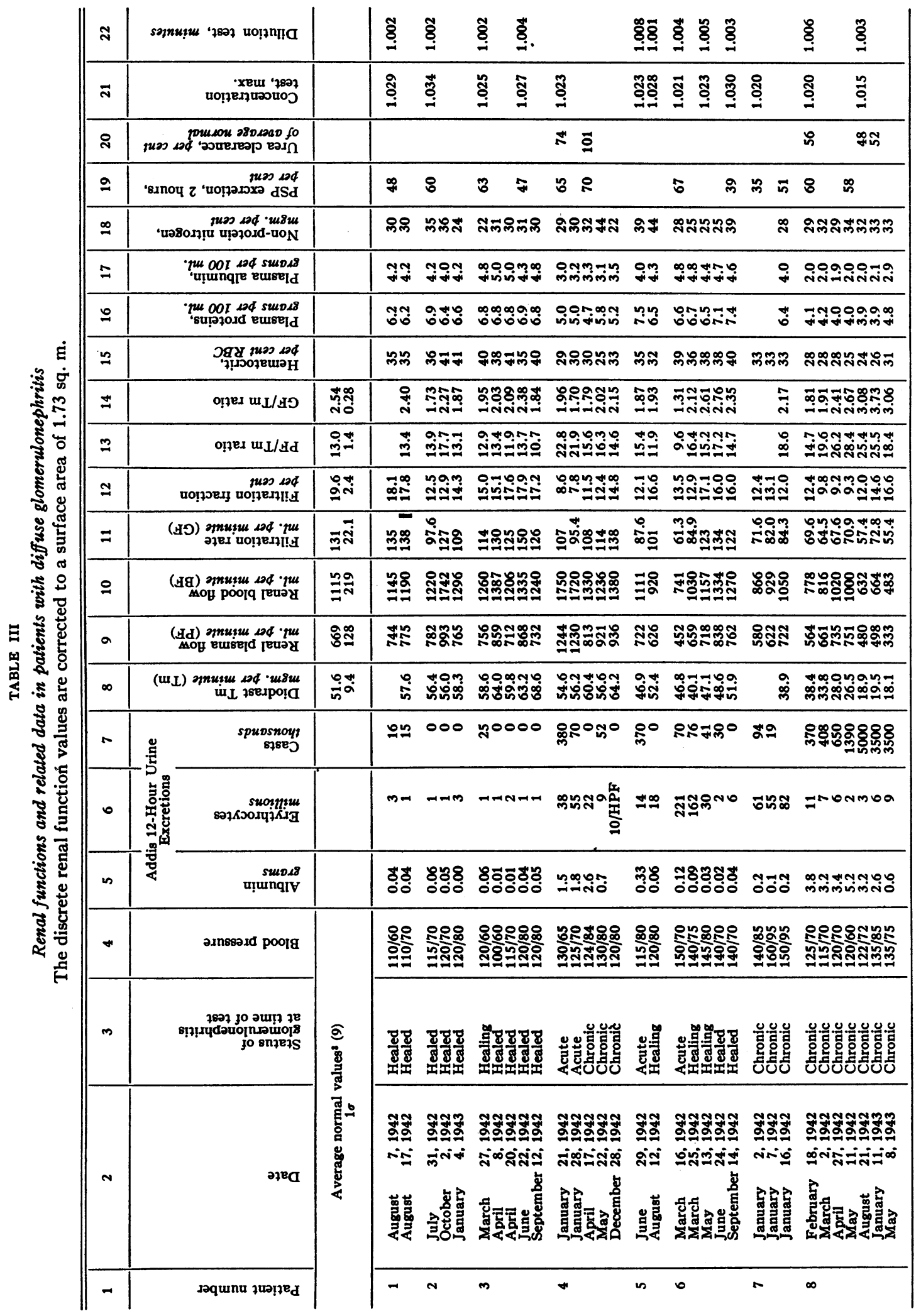




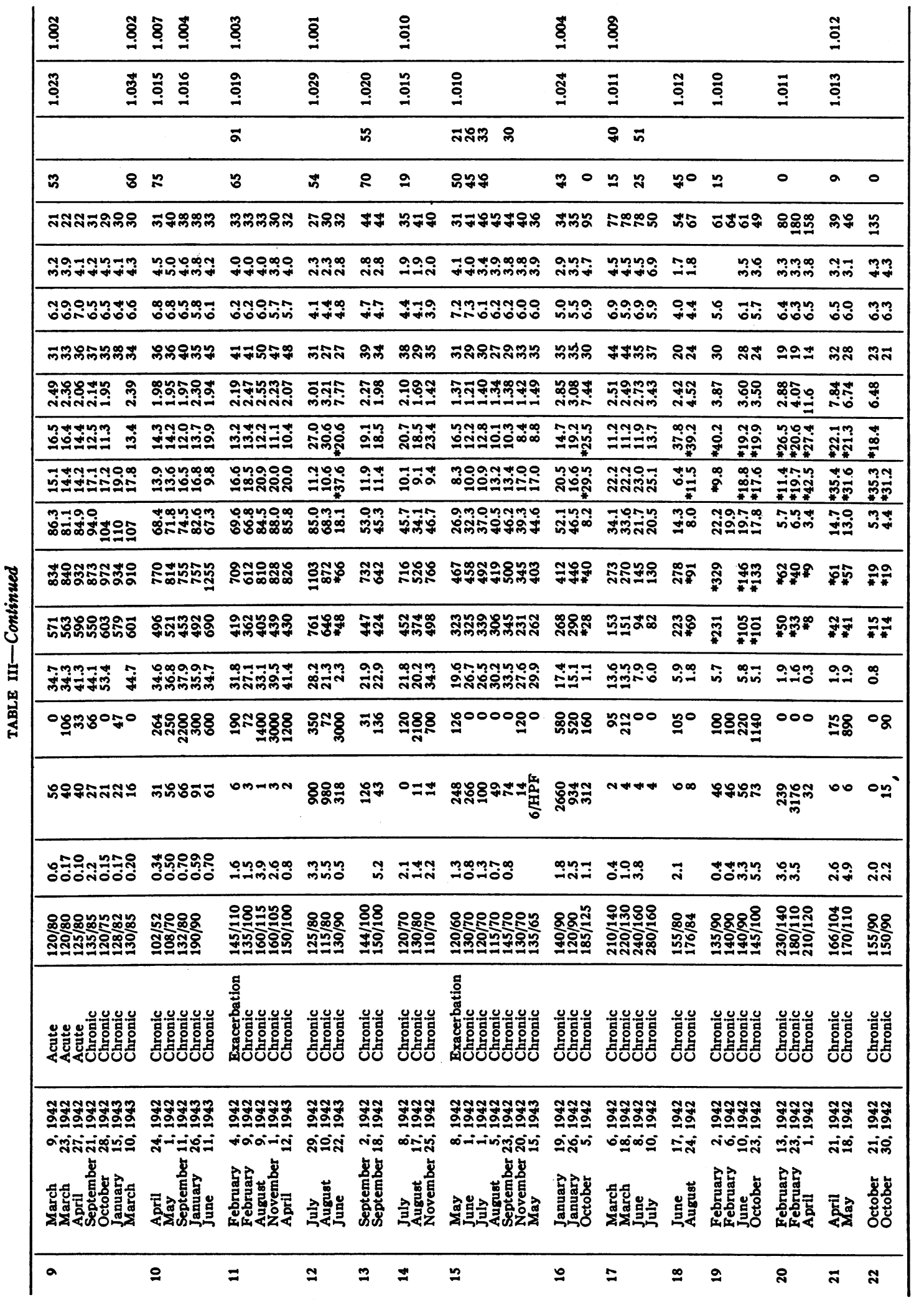


are essential to saturate the transfer mechanism for diodrast (23), as in fact appears to be the case for phenol red in the normal subject.

It may be assumed for our present purposes that the maximal clearance of diodrast can only constitute a valid approximation of the renal plasma flow when determined at plasma concentrations below the level where the tubular excretion is directly proportional to the load of diodrast presented to the tubules. Also, it appears improbable from the data in Figure 1 that a valid plasma flow can be obtained with present chemical methods in these patients with $\mathrm{Tm}$ values much below $6.0 \mathrm{mgm}$. of diodrast iodine per minute. The lowest plasma levels of diodrast compatible with accurate chemical analysis may be expected to result in a tubular excretion of diodrast which, in these individuals, is not proportional to the plasma load. The apparent renal plasma flow of patients with a $\mathrm{Tm}$ value below $6.0 \mathrm{mgm}$. per minute has been recorded in the summary of results (Table III) but is marked by an asterisk, as are the derived relationships.

The estimation of filtrate fraction. This datum, being the dividend of the glomerular filtration rate and the renal plasma flow, is equal to the fraction of the plasma water which, reaching the glomeruli of the normal kidney, is filtered in the process of achieving pressure equilibrium across the glomerular membrane $(8,9,24,25)$. As such, the filtrate fraction, together with the absolute values of glomerular filtration rate and renal plasma flow, yields information on the hemodynamics of glomerular action. The value of the normal figure is $0.196(\sigma= \pm 0.024)$. This is the net result of the operation of arterial pressure and mean resistance at the afferent and efferent arterioles, in so far as these define intracapillary pressure and those factors which determine the plasma oncotic pressure and the intracapsular pressure which oppose intracapillary pressure. Also concerned are those factors relating to the characteristics of the glomerular membrane and rate of plasma flow which, together with the pressure relationships, determine the degree to which pressure equilibrium is achieved in the glomeruli. Changes in the filtrate fraction from the normal value are, therefore, of some aid in the interpretation of the functional organization of glomerular action in any situation, providing the same sig- nificance can be attached to the data as in the normal subject. The latter appears to be probable in glomerulonephritis in those situations where the plasma clearance of diodrast has physiological significance (see above).

Diodrast $T m$. Diodrast $T m$ may be accepted as a functional expression of the amount of tubular tissue $(8,9,21,25)$. Recently, it has been demonstrated that the magnitude of the diodrast $\mathrm{Tm}$ may be affected by non-renal factors. It seems likely, however, that the progressive, systematic changes in the diodrast $\mathrm{Tm}$ values which have been observed in this study are for the most part a reflection of the loss of renal substance or the alteration of renal tubular function as a result of the diffuse glomerulonephritis. This view is emphasized by the fact that significant changes in diodrast $\mathrm{Tm}$ in individual normal (9) or hypertensive subjects (26) are unusual over considerable periods of time.

\section{RESULTS}

The data obtained in each of the patients studied is summarized in Table III. The tabulation includes information on the renal plasma flow, renal blood flow, glomerular filtration rate and diodrast Tm (all corrected to a standard surface area of 1.73 sq. m.), the filtrate fraction, and the $\mathrm{PF} / \mathrm{Tm}$ and $\mathrm{GF} / \mathrm{Tm}$ ratios. The table also includes normal values for each of the functions studied ${ }^{3}$ (9). The values for plasma flow, filtrate fraction, and the ratio $\mathrm{PF} / \mathrm{Tm}$ which are marked by an asterisk are from studies where the evidence indicates that the diodrast clearance is no longer a close approximation of the renal plasma flow. The renal plasma flow and plasma flow to diodrast $\mathrm{Tm}$ ratio will be lower under these circumstances and the filtrate fraction higher than actually obtains. Other clinical data which bear on the status of the patient at the time of the clearance study are included in Table III. These observations were usually made within a day or two of the clearance study and in all cases were sufficiently close for them to be accepted as characteristic of that time.

The data indicate that a reduction in the amount

\footnotetext{
8 The normal values for the filtrate fraction and the $\mathrm{PF} / \mathrm{Tm}$ ratio were calculated from the renal plasma flow, glomerular filtration rate, and diodrast $\mathrm{Tm}$ figures, given in Table IV of the paper of Goldring, Chasis, Ranges, and Smith (9).
} 


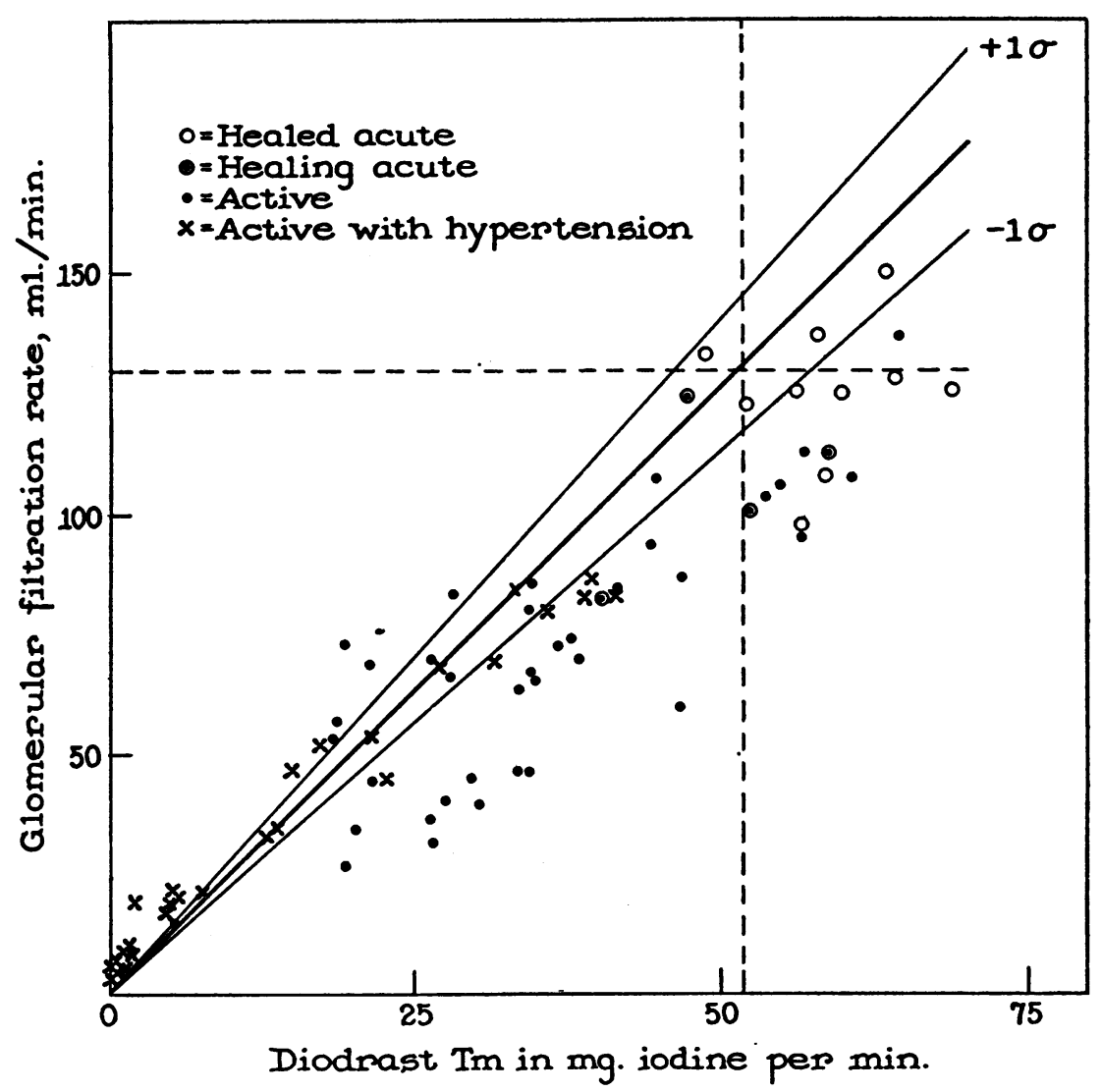

Fig. 2. Glomerular Filtration Rate in Relation to Diodrast Ty in a Series of Patients with Diffuse Glomerulonephritis *

The mean normal values for these functions are shown by the dotted lines; the normal relation between the $2(\mathrm{GF} / \mathrm{Tm}=2.54, \sigma= \pm 0.28)$, by the diagonal lines. Each datum in this and subsequent figures represents the average of 2 or more consecutive clearance periods.

of functional renal parenchyma, as measured by diodrast $\mathrm{Tm}$, is usually accompanied by a roughly parallel decrease in glomerular filtration rate and in renal plasma flow; the former appears to be a much more sensitive indicator of the disturbance in renal function in this situation. Actually, a reduction in the renal plasma flow was not consistently noted until the diodrast $T \mathrm{~m}$ value was below $30 \mathrm{mgm}$. of iodine per minute. However, as renal damage progressed beyond this value for the diodrast $\mathrm{Tm}$, there was a rapid decrease in the plasma flow to very low values. These relations are illustrated graphically in Figures 2 and 3.4

4 Figures 2, 3, and 5 were patterned after those of Goldring, Chasis, Ranges, and Smith (26). See also footnote 3 .
Figure 2 presents the relationship observed between glomerular filtration rate and diodrast $\mathrm{Tm}$. The mean normal values for the variables are indicated by the horizontal and vertical lines; the normal relation between the two, by the solid diagonal line. Data obtained after the healing of an acute diffuse glomerulonephritis are indicated by open circles; those obtained during the healing or probable healing, by dotted circles; and the remainder (active), by solid circles, or by crosses when the diastolic blood pressure was in excess of $90 \mathrm{~mm}$. of $\mathrm{Hg}$. The data indicate that a reduction in glomerular filtration rate is generally accompanied by a decrease in the amount of functional tubular tissue, and also that patients with active diffuse glomerulonephritis characteristically have low GF/Tm ratios until the diodrast iodine 


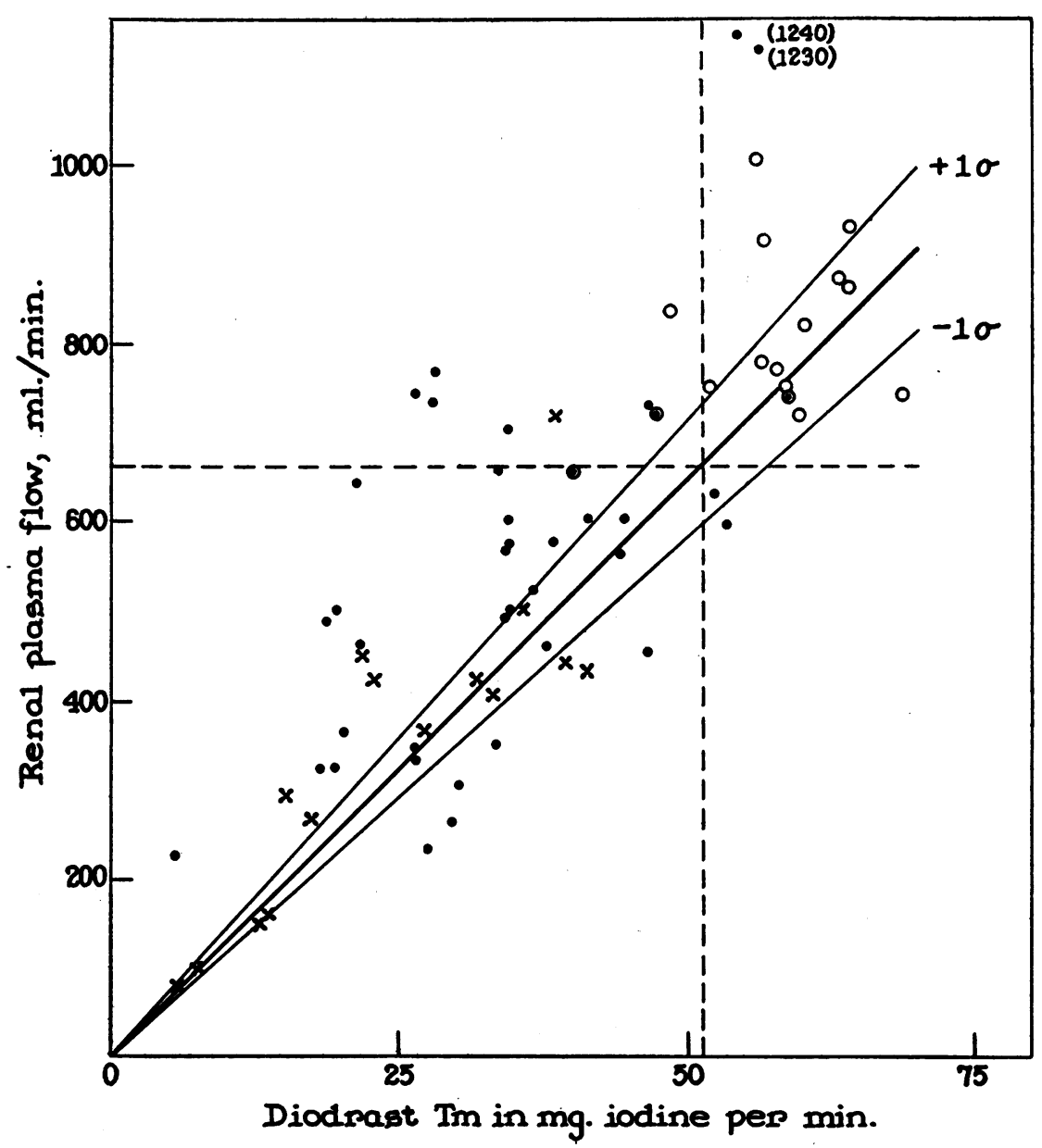

Fig. 3. Renal Plasma flow in Relation to Diodrast Ty in a Sertes of Patients with Diffuse Glomerulonephritis ${ }^{8,4}$

The mean normal values for these functions are shown by the dotted lines; the normal relation between the $2(P F / T m=13.0, \sigma= \pm 1.4)$, by the diagonal lines. The status of the nephritis at the time of each observation is indicated as in Figure 2. Only valid renal plasma determinations are included.

Tm drops below $20 \mathrm{mgm}$. per minute. The progress of renal damage beyond this value involves a preferential loss of tubular tissue, or of some functional capacity of tubular tissue to do a specific type of work (i.e., transfer diodrast), as compared to the ability of glomeruli to filter water and solute.

The relationship between renal plasma flow and diodrast $\mathrm{Tm}$ is summarized in Figure 3. This figure includes only those observations wherein the diodrast clearance is believed to be a close approximation of the renal plasma flow (see above). The general status of the nephritis at the time of the examination is indicated by different symbols, as in Figure 2. The mean normal values for the two variables are indicated by the horizontal and vertical lines; the normal relation between the two, by the solid diagonal line. The general reduction in renal plasma flow which accompanies the reduction in diodrast $\mathrm{Tm}$ is illustrated by the figure. However, it should be noted that high $\mathrm{PF} / \mathrm{Tm}$ ratios are not uncommon in all stages of diffuse glomerulonephritis and also that when the status of the nephritis is complicated by the presence of hypertension, the observations do not depart from the usual relationship 
in any systematic manner. It should be noted further that the scatter of the data is such that a close correlation between the two variables is not a characteristic of the pattern of renal function in glomerulonephritis.

A low filtrate fraction is one of the most consistent findings among these patients with diffuse glomerulonephritis, irrespective of the stage of the disease. This was still apparent in 1 (Patient 2 ) of the 2 patients studied only after healing, and in 15 of the 20 patients studied during the course of diffuse glomerulonephritis. The studies were made so late in the course of the disease in 2 of the 5 exceptions (Patients 21 and 22) that valid filtrate fraction values were not obtained. The figures recorded for these patients in Table III are higher than the true values.

The valid filtrate fractions obtained in this series of observations are plotted in relation to diodrast $\mathrm{Tm}$ in Figure 4. The mean normal filtrate fraction of $19.6(\sigma= \pm 2.4)^{3}$ per cent is shown by the solid horizontal lines. The general status of the nephritis at the time of the examination is indicated by different symbols as in Figure
2. The graphical summary emphasizes the frequency with which low filtrate fractions obtain in patients with active diffuse glomerulonephritis. Those with diastolic blood pressures above $90 \mathrm{~mm}$. of mercury contributed almost all the normal and all the high filtrate fractions in the patients with diodrast iodine $\mathrm{Tm}$ values below $40 \mathrm{mgm}$. per minute. It should be noted, however, that hypertension is not inconsistent with a low filtrate fraction, as evidenced by the 3 observations with values of 0.12 or lower (Patients 7 and 13). The filtrate fraction is plotted against the $\mathrm{PF} / \mathrm{Tm}$ ratio in Figure 5 and it may be seen that many of the observations fall outside and below the normal parameters, and also that the filtrate fractions of the patients with hypertension are distributed somewhat differently than the remainder.

The relation between the functional mass of tubule tissue (Diodrast $\mathrm{Tm}$ ) and the diastolic blood pressure in the patients is shown in Figure 6. Diastolic hypertension does not appear to be a consistent finding, except during an acute episode, until diodrast iodine $\mathrm{Tm}$ falls below 20 mgm. per minute, although it is occasionally found

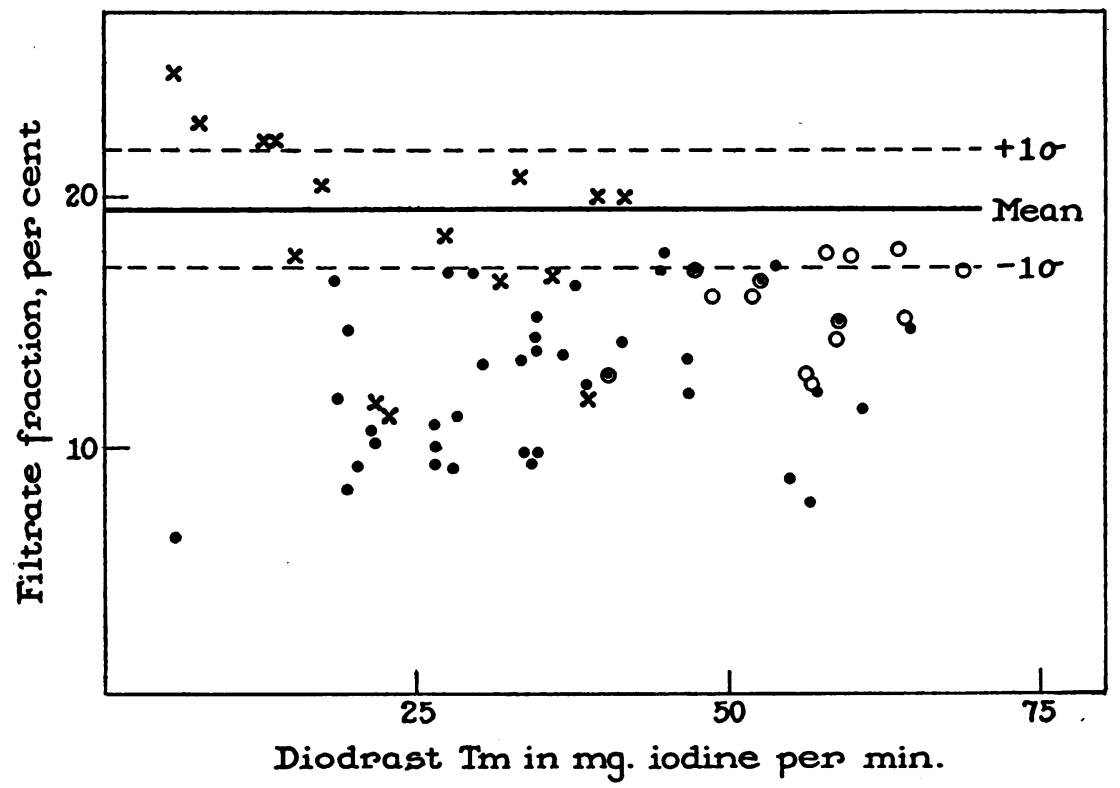

Fig. 4. Filtrate Fraction in Relation to Diodrast TM in a Series of Patients with Diffuse Glomerulonephritis ${ }^{8}$

The mean normal filtrate fraction ( $G F / P F=19.6$ per cent, $\sigma= \pm 2.4$ per cent) is shown by the horizontal lines. The status of the nephritis at the time of each observation is indicated as in Figure 2. Only filtrate fractions based on valid renal plasma flow determinations are included. 
in nephritic subjects whose $\mathrm{Tm}$ values are considerably higher.

It has been shown that the renal vascular tree of normal individuals (24) and patients with essential hypertension (26) reacts to pyrogenic material in a manner which produces a marked increase in the renal blood flow. The renal hyperemia is not associated with a significant change in glomerular filtration rate, so that there is an associated fall in the filtrate fraction. Patients 9, 10,12 , and 15 were selected for a limited examination of this phenomenon in glomerulonephritis, and typhoid vaccine (24) was used as the pyrogenic agent. Three of the 4 patients showed a typical reaction, whereas there was a reduction of the filtrate fraction of Patient 12 which was a simple reflection of the fall in glomerular filtration rate. However, the injection of typhoid vaccine in this instance was followed by a severe general reaction and the observation was complicated by the incidental vascular phenomena.

It was anticipated that a study of the discrete renal functions and their interrelationships during the initiation and early stages of acute glomerulonephritis would permit an early differentiation of those patients who subsequently recovered completely, as compared to those who passed into a chronic phase. Such a differentiation has not been achieved in the data collected to date but it may be noted that information on the renal status of the patients during the first week or two following the inception of the disease is not available.

It is of some interest that, in the interval following the acute attack, there was no significant reduction of the absolute values of renal plasma flow, glomerular filtration rate, or diodrast $\mathrm{Tm}$, in Patients 3 and 4, although the filtrate fractions and GF/Tm ratios did reveal abnormal relations. The nephritis of Patient 3 healed, the filtrate fraction rising to normal, but the nephritis of Patient 4 did not heal, although the filtrate fraction showed some progressive improvement. The remaining subjects with acute glomerulonephritis (Patients 5, 6, and 9) showed definite depressions of glomerular filtration rate or diodrast $\mathrm{Tm}$, as well as of the filtrate fraction and GF/Tm ratio.

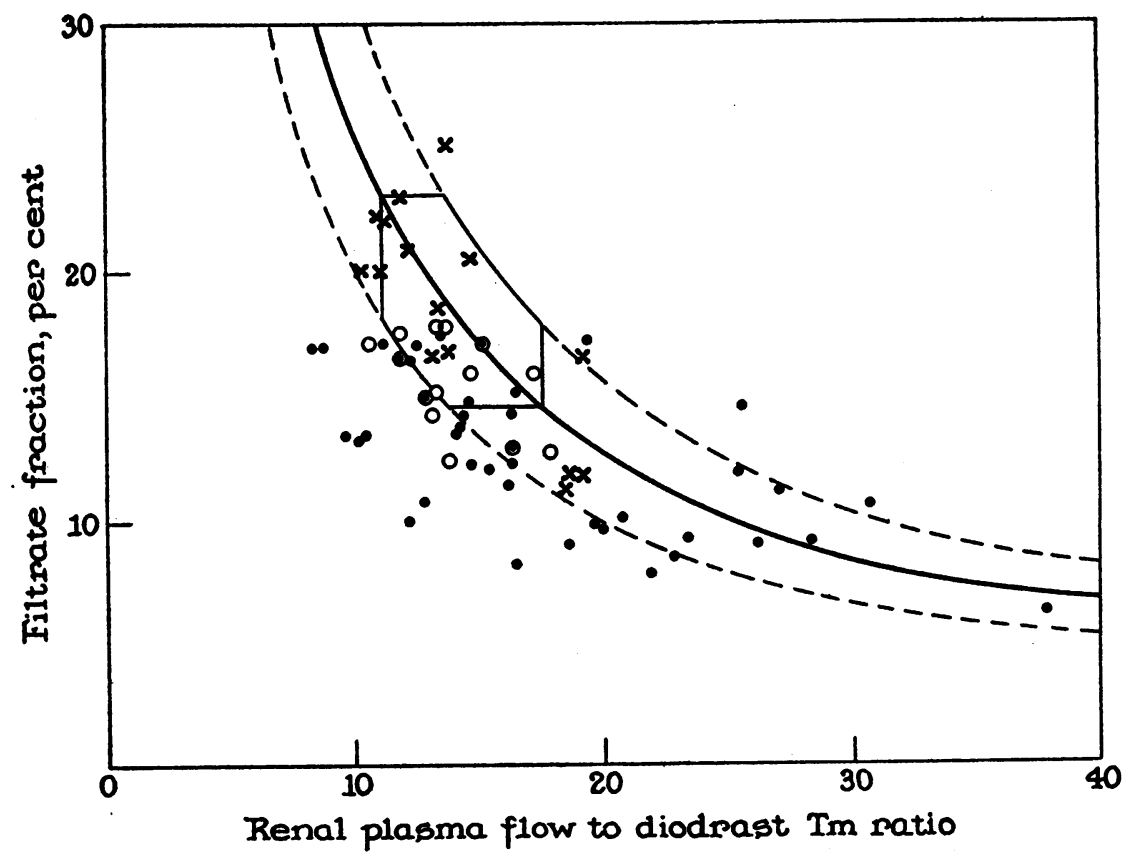

Fig. 5. Filtrate fraction in Relation to the Plasma flow to Diodrast Ty Ratio in a Series of Patients with Diffuse Glomerulonephritis 8,

The hexagon contains 95 per cent of normal basal data (26). The status of the nephritis at the time of each observation is indicated as in Figure 2. Only data based on valid renal plasma flow determinations are included. 


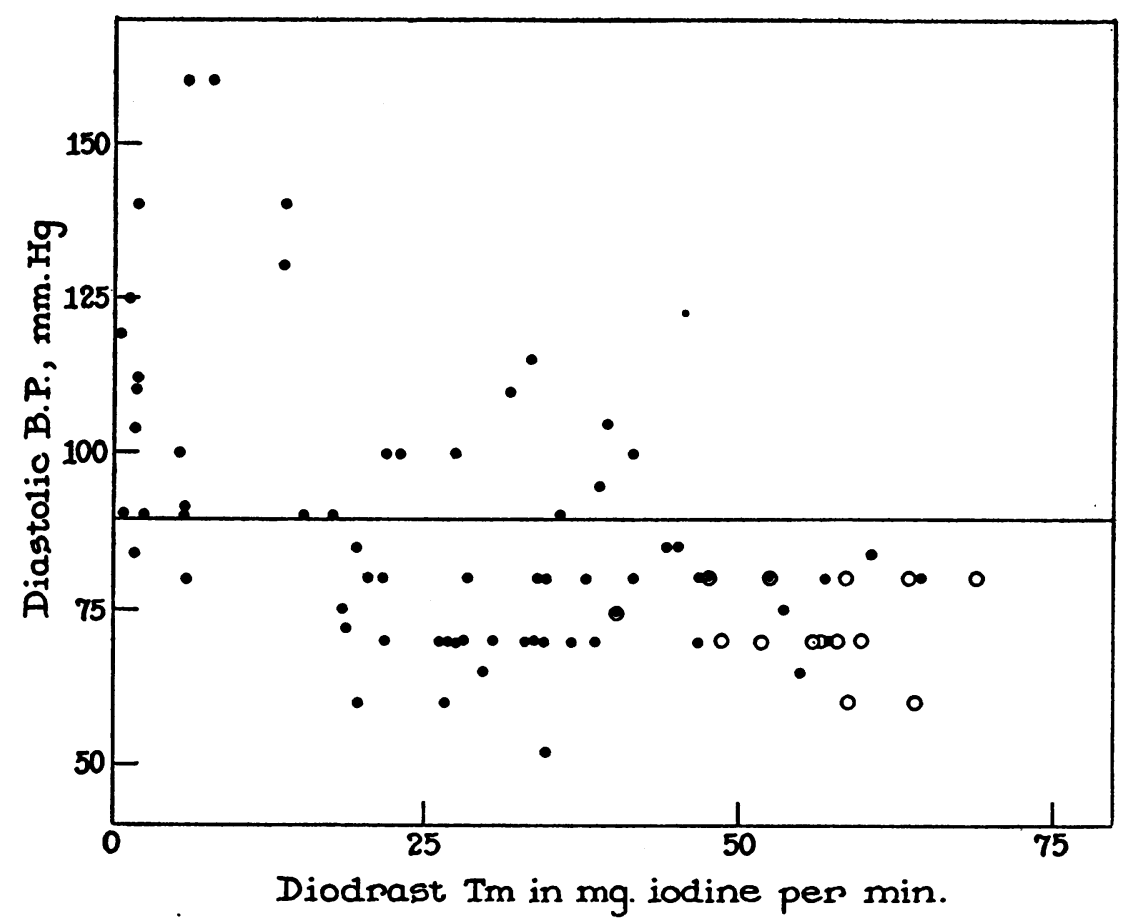

Fig. 6. Diastolic Blood Pressure in Relation to Diodrast Tm in a Series of Patients with Diffuse Glomerulonephrits

The status of the nephritis at the time of each observation is indicated as in Figure 2. The upper limit of normal diastolic blood pressure $(89 \mathrm{~mm} . \mathrm{Hg})$ is indicated by the horizontal line.

The nephritis healed in Patient 6, while the process was definitely improving in Patients 5 and 9 when last studied. The discrete functions and the filtrate fraction and GF/Tm ratio in all 3 returned to normal or almost normal values and evidence of continuing kidney damage was derived largely from studies on the renal excretion of albumin and formed elements. Patient 2 still showed a low filtrate fraction $101 / 2$ months after the onset of an acute glomerulonephritis that healed according to the ordinary clinical criteria. There is, then, no apparent correlation in these patients between the degree of functional impairment at the time the patient was first seen and the eventual outcome of the acute glomerulonephritis.

Patients 11 and 15 were observed shortly following exacerbations in their chronic glomerulonephritis. The diodrast $\mathrm{Tm}$ gradually rose in Patient 11 to a low normal value during the 22 months following the acute episode. The glomerular filtration rate meanwhile rose slightly but did not attain a normal value. The exacerbation of
Patient 15 produced a more severe depression of various functions studied and a greater distortion of their interrelationships. Some gradual improvement was noted in the rate of glomerular filtration and in the diodrast $\mathrm{Tm}$, but these functions eventually stabilized at quite low values. The filtrate fraction rose from 8 per cent to a low normal value, but the GF/Tm ratio remained depressed. An exacerbation also occurred in Patient 12 during the period of observation. The effect of this episode on the progress of the disease could not be determined however, since 7 months elapsed between the time of the exacerbation and the final renal function study.

It is probable that more numerous studies in patients before, during, and after exacerbations will aid in determining the importance of such episodes in conditioning the overall rate of progression of the disease (4). The usefulness of measurements of these functional measurements in yielding information on the rate of the progression as well as on the amount of residual renal 
tissue is brought out by the observations on $\mathrm{Pa}$ tients $8,12,16,17$, and 20 . All of these patients were in the chronic phase of the disease. Patients $8,12,16$, and 17 were observed serially over considerable periods of time and showed a steady decline in glomerular filtration rate and diodrast Tm. Patient 20, first seen in the terminal phase of the disease $(\mathrm{Tm}=1.91)$, manifested a further decline in both glomerular filtration rate and diodrast $\mathrm{Tm}$ in the subsequent weeks, prior to death. The PSP test throughout the period of observation in this patient was zero. The declines in glomerular filtration rate in these patients would presumably have been reflected in similarly decreasing urea clearances had these been systematically observed.

In direct contrast to the patients who manifested a progressive impairment of renal function while under observation, Patient 10, studied 8 years after the initial diagnosis of chronic glomerulonephritis, showed no significant change in diodrast Tm and a slight and temporary but definite increase in glomerular filtration rate over a 9-month interval. The improvement of diodrast $\mathrm{Tm}$ in Patient 14 was more striking. Such improvements of the renal function of patients with long-standing chronic glomerulonephritis are difficult to understand and may represent improvement subsequent to undetected exacerbations.

\section{DISCUSSION}

A survey of 22 patients in various phases of diffuse glomerulonephritis indicates, as is to be expected, that the advance of the disease is associated with progressive depression of the renal plasma flow, the glomerular filtration rate, and the mass of functional tubular tissue as reflected by the diodrast $\mathrm{Tm}$. The interrelations of the discrete functions also depart from the normal and yield additional information on the functional organization of the kidney in this disease.

Glomerular changes are perhaps the outstanding anatomical lesion of diffuse glomerulonephritis, early in the course of the disease. These changes commonly consist of a thickening of the capsule and basement membrane and an increased cellularity of the tuft. The arterioles of the glomeruli and the renal tubules are not extensively involved at this stage. The frequent finding of a reduced filtration rate, low filtrate fraction, and low GF/Tm ratio would appear to be a functional expression of such a morphological change. Progress in the disease is then accompanied by a progressive ablation of renal tubular as well as glomerular tissue, and all functions fall in a roughly parallel manner with the maintenance of an abnormally low filtrate fraction. The later stages of the disease appear to be accompanied by a greater acceleration in the loss of tubular rather than glomerular tissue or function. This circumstance is reflected in the high GF/Tm ratios and the relatively low values for the diodrast clearance. The latter stage of the disease is not amenable to simple analysis because of the difficulty in estimating renal plasma flow, as well as the frequent entrance of a complication in the form of a persistent hypertension. The latter may be expected to produce a disturbance in both systemic and glomerular hemodynamics.

The abnormally low filtrate fraction is a reflection of the glomerular changes which effect a greater barrier to the maintenance of glomerular filtration than to the passage of blood through the glomerular apparatus. Viewed in this light, it is not surprising that some of the patients manifest an actual renal hyperemia (Patient 4 ) whereas in others this is simply reflected in a low filtrate fraction and reciprocal changes in the GF/Tm and $\mathrm{PF} / \mathrm{Tm}$ ratios. The low filtrate fraction may be attributed to changes in the character of the filtering bed which prevent the attainment of pressure equilibrium in each glomerulus, or it may be the result of those factors which determine the equilibrium pressure within the glomeruli. The increased renal plasma flow produced by typhoid vaccine in nephritic patients indicates that the glomerular arterioles are capable of normal reaction in this situation. It is difficult to define the relative importance of each of the various factors which are concerned in determining the change in the filtrate fraction. However, it would be in keeping with the usual pathological findings in diffuse glomerulonephritis to assign a major role to those factors which together determine the rate at which pressure equilibrium across the glomerular membrane is achieved, rather than to those factors which together determine the order of magnitude of the pressures across the membrane. It should be noted in Columns 15 and 17 of Table III that many of the nephritic patients 
had low hematocrit and plasma albumin values. An analysis (not presented here) of the relation of these factors to renal plasma flow, glomerular filtration rate, and filtrate fraction suggests that changes among these are dependent upon the disease itself rather than upon any direct relationships between the two groups of factors.

The early impairment of glomerular filtration rate, the low filtrate fraction, and the low GF/Tm ratios of diffuse glomerulonephritis are opposed to the usual findings in essential hypertension (26, 27, 28). Examination of Table III and Figure 3 indicates that patients with diffuse glomerulonephritis, with or without hypertension, do not commonly have low $\mathrm{PF} / \mathrm{Tm}$ ratios. The graphical plot of the data in Figure 5, however, suggests that the presence of a hypertension in patients with diffuse glomerulonephritis may change the dynamics of glomerular action in such a way that there is an increase in filtrate fraction, above values generally found among non-hypertensive nephritics. It may be noted in addition that hypertension is not necessarily related to a reduction of the amounts of functional tissue, as measured by diodrast Tm, except in that it become more common with progressive lowering of the latter function (Figure 6). However, diastolic hypertension is not found with any considerable regularity until the $\mathrm{Tm}$ has been reduced below $20 \mathrm{mgm}$. of diodrast iodine per minute.

The data upon which the above discussion is based are presented graphically in Figures 2 to 6 which contain all acceptable experiments, done in patients whose diagnoses of diffuse glomerulonephritis were reasonably certain. The status of renal disease in the various patients varied from healed acute glomerulonephritis to terminal uremia. In some patients, the disease was not stationary during the periods of recovery or improvement after acute episodes, while in others, progressive deterioration of renal function was observed. It seems likely, therefore, that the data presented give a fair cross-sectional view of the effects of diffuse glomerulonephritis on the functional organization of the kidneys.

The data reported in this paper contain certain more general implications which may be related to some of the clinical manifestations of diffuse glomerulonephritis. The discrete renal functions in normal subjects may be viewed as if they were occurring in a single nephron $(25,29)$. This opinion rests upon the demonstration that all nephrons in the dog (29) and probably in man (30) are continuously active, and that the reabsorptive capacities of the individual tubules are closely correlated with the ability of their attached glomeruli to filter (29). It may be expected, in consequence of this, that symptoms of renal injury may become manifest because of an absolute deficiency in the number of residual nephrons or because of a general distortion of the normal relationships of the component parts of some or all the nephrons. The data indicate that in glomerulonephritis all of these factors probably operate throughout the course of the disease and that its early stages are characterized by a loss of the normal balanced relationship between glomerulus and tubule in at least a major portion of the nephrons. An anatomical basis for this judgment exists in the presence of all possible combinations of glomerular and tubular injury, throughout the course of the disease (31).

It may be anticipated from these considerations that the distortion of the normal quantitative relationship between glomerular and tubular function has important consequences to those mechanisms which are important in determining the rate of excretion of water and electrolyte. This judgment presupposes that these factors are similar in man to those demonstrated for the dog, and that while diodrast $\mathrm{Tm}$ is probably not directly proportional to the ability of the tubules to reabsorb sodium and other electrolytes, it is likely that impairment of one tubular function will be accompanied by impairment of others. In nephritis, then, glomerular damage out of proportion to the impairment of tubular function should predispose to the retention of electrolyte and, incidentally, water, as is so common. The opposite combination, however, may contribute to the demineralization which is also seen frequently, but later in the course of the disease. It may be calculated, furthermore, that a small percentage of nephrons, continuously diuretic because of an impairment in electrolyte absorption (32), can result in a urine of low specific gravity. This could explain the relatively long persistence of impaired concentrating power, frequently noted after healed 
acute diffuse glomerulonephritis. The final definition of these problems, however, awaits more extensive studies.

\section{SUMMARY AND CONCLUSIONS}

1. The glomerular filtration rate (GF), renal plasma flow (PF), and maximal rate of tubular excretion of diodrast $(\mathrm{Tm})$ have been studied in a series of 22 patients in various phases of diffuse glomerulonephritis. There is a depression of all 3 functions as the disease advances, associated with marked distortions in their normal relationships. The glomerular filtration rate is the most sensitive indicator of renal change early in the course of the disease. This is reflected by a low filtrate fraction and a low GF/Tm ratio.

2. Acute glomerulonephritis and exacerbations in chronic glomerulonephritis may be associated with depression of glomerular filtration rate, diodrast $\mathrm{Tm}$, filtrate fraction, and $\mathrm{GF} / \mathrm{Tm}$ ratio. Any or all of these values may return toward normal as improvement or healing of the acute process occurs. There may be a transient hyperemia as well, indicated by a high $\mathrm{PF} / \mathrm{Tm}$ ratio. No correlation has been apparent between changes in specific renal functions or their relationships in acute glomerulonephritis and the eventual outcome of the disease.

3. As chronic glomerulonephritis progresses, the tubular function undergoes relatively greater impairment than the glomerular filtration rate, indicated by high GF/Tm ratios and a relatively excessive lowering of the diodrast clearance.

4. The development of hypertension has not been specifically related to the residual kidney mass, although it is not infrequent when there has been more than a 40 per cent reduction in $\mathrm{Tm}$.

5. Certain implications of the results have been discussed.

\section{BIBLIOGRAPHY}

1. Miller, B. F., Alving, A. S., and Rubin, J., The renal excretion of inulin at low plasma concentrations of this compound, and its relationship to the glomerular filtration rate in normal, nephritic and hypertensive individuals. J. Clin. Invest., 1940, 19, 89.

2. Steinitz, K., Zur Frage der Nierendurchblutung bei Normalen, Hypertonikern und Nierenkranken. Acta Med. Scandinav., 1941, 109, 95.

3. Findley, T., Edwards, J. C., Clinton, E., and White, H. L., Clearance of diodrast, phenolsulfonphthalein and inulin in hypertension and in nephritis. Arch. Int. Med., 1942, 70, 935.

4. Seegal, D., Lyttle, J. D., Loeb, E. N., Jost, E. L., and Davis, G., On the exacerbation in chronic glomerulonephritis. J. Clin. Invest., 1940, 19, 569.

5. Winkenwerder, W. L., McLeod, N., and Baker, M., Infection and hemorrhagic nephritis. Arch. Int. Med., 1935, 56, 297.

6. Bloom, W. L., and Seegal, D., Unpublished data.

7. Williams, R. H., Longcope, W. T., and Janeway, C. A., Use of sulfanilamide in the treatment of acute glomerular nephritis. Am. J. M. Sc., 1942, 203, 157.

8. Smith, H. W., Goldring, W., and Chasis, H., The measurement of the tubular excretory mass, effective blood flow and filtration rate in the normal human kidney. J. Clin. Invest., 1938, 17, 263.

9. Goldring, W., Chasis, H., Ranges, H. A., and Smith, H. W., Relations of effective renal blood flow and glomerular filtration to tubular excretory mass in normal man. J. Clin. Invest., 1940, 19, 739.

10. Shannon, J. A., and Smith, H. W., The excretion of inulin, xylose and urea by normal and phlorizinized man. J. Clin. Invest., 1935, 14, 393.

11. Smith, W. W., Finkelstein, N., and Smith, H. W., Renal excretion of hexitols (sorbitol, mannitol and dulcitol), and their derivatives (sorbitan, isomannide and sorbide) and of endogenous creatininelike chromogen in dog and man. J. Biol. Chem., 1940, 135, 231.

12. Brodie, B. B., Unpublished observations.

13. Alpert, L. K., A rapid method for the determination of diodrast-iodine in blood and urine. Bull. Johns Hopkins Hosp., 1941, 68, 522.

14. Fujita, A., and Iwatake, D., Bestimmung des echten Blutzuckers ohne Hefe. Biochem. Ztsch., 1931, 242, 43.

15. Somogyi, M., Method of preparation of blood filtrates for determination of sugar. J. Biol. Chem., 1930, 86, 655.

16. Harrison, $H$. E., A modification of the diphenylamine method for the determination of inulin. Proc. Soc. Exper. Biol. and Med., 1942, 49, 111.

17. Alving, A. S., Rubin, J., and Miller, B. F., A direct colorimetric method for the determination of inulin in blood and urine. J. Biol. Chem., 1939, 127, 609.

18. Pregl, F., Die quantitative organische Mikroanalyse. Berlin, 1923, 2nd edition.

19. Howe, P. E., The use of sodium sulfate as the globulin precipitant in the determination of proteins in blood. J. Biol. Chem., 1921, 49, 93.

20. Addis, T., A clinical classification of Bright's diseases. J. A. M. A., 1925, 85, 163.

21. Smith, H. W., Note on the interpretation of clearance methods in the diseased kidney. J. Clin. Invest., 1941, 20, 631.

22. Smith, H. W., et al., The application of saturation methods to the study of glomerular and tubular 
function in the human kidney. J. Mt. Sinai Hosp., 1943, 10, 59.

23. Shannon, J. A., Renal tubular excretion. Physiol. Rev., 1939, 19, 63.

24. Chasis, H., Ranges, H. A., Goldring, W., and Smith, H. W., The control of renal blood flow and glomerular filtration in normal man. J. Clin. Invest., 1938, 17, 683.

25. Shannon, J. A., Kidney. Ann. Rev. Physiol., 1942, 4, 297.

26. Goldring, W., Chasis, H., Ranges, H. A., and Smith, H. W., Effective renal blood flow in subjects with essential hypertension. J. Clin. Invest., 1941, 20, 637.

27. Chesley, L. C., and Chesley, E. R., Renal blood flow in women with hypertension and renal impairment. J. Clin. Invest., 1940, 19, 475.
28. Foa, P. P., Woods, W. W., Peet, M. M., and Foa, N. L., Effective renal blood flow, glomerular filtration rate and tubular excretory mass in arterial hypertension. Arch. Int. Med., 1942, 69, 822.

29. Shannon, J. A., Farber, S., and Troast, L., Measurement of glucose Tm in normal dog. Am. J. Physiol., 1941, 133, 752.

30. Smith, H. W., Ranges, H. A., Chasis, H., and Goldring, W., The dispersion of glomerular activity in the normal and hypertensive kidney. Am. J. Physiol., 1941, 133, 450.

31. Oliver, J., Architecture of the Kidney in Chronic Bright's Disease. P. Hoeber, New York, 1939.

32. Shannon, J. A., The control of the renal excretion of water. I. The effect of variations in the state of hydration on water excretion in dogs with diabetes insipidus. J. Exper. Med., 1942, 76, 371. 